Dealing with the Antarctic expedition, the authors turn from one problem to another; from engaging the reader's interest in the story of an obscure and largely uneventful life to maintaining interest in yet another re-telling of one of the most famous stories in the world. Once again, it is the careful use of Oates's own writings-including extracts made by Violet Oates from his polar diary (the original having been destroyed on instructions from her mother)-that enables the authors to add freshness and insight to the story. The diary and letters reveal, for example, that Oates, almost alone among Scott's men, was able to admire the hated rival Amundsen for his toughness and superior organization, even in the moment of defeat after arriving second to Amundsen at the pole: 'I must say that man must have had his head screwed on right. The gear they left was in excellent order and they seem to have had a comfortable trip with their dog teams very different from our wretched man-hauling'.

His cool, unemotional objectivity at that time of agonizing humiliation for Scott's pole party gives a little insight into the clear-headed detachment with which Oates could handle the worst of circumstances. It was a quality of mind that had been present in glimpses throughout his army career, clearly demonstrated in the Boer War, but called upon altogether too infrequently, for his taste, in the frustrating years thereafter. But now, at the very end, he showed that quality in full measure. Within two months of recording his equanimity in defeat at the Pole, Oates faced the gravest of crises: crippled with frostbite, he was hindering his companions in their race towards safety. Displaying again that cool detachment, he spotted their one chance of survival and walked out of the tent to his death.

'Hero or victim?' is the title of this book's last chapter; an examination of the ways in which succeeding generations have viewed his death, reflecting the doubts that have sometimes been cast on the value of Oates's self-sacrifice and, indeed, on the value of the whole tragic polar endeavour. But there is no need by this stage to wonder how the authors will answer their own question; throughout the book they have sympathetically and persuasively portrayed Oates as an amiable, essentially uncomplicated, but quietly most competent soldier who would never have coveted the label of hero, but, at the same time, was nobody's victim. Throughout his short life he yearned for adventure, but he did not close his eyes to the risks that adventure involved. In the end, the risks overwhelmed him, and he quietly accepted the consequences. Despite the doubters, posterity has elected him a hero, and this excellent book has emphatically endorsed, and let us hope reinforced, posterity's judgement.

One minor niggle. Those 340-odd letters from Oates to his mother have in recent years found a permanent home in the Scott Polar Research Institute, thanks to the generosity of many benefactors who enabled the Institute to purchase them, as it were, for the nation. It would have been both courteous and useful for the authors to tell us so, but for some odd reason they are content to record only that the letters 'are known to still exist'.

\title{
STARVING SAILORS
}

[Review by G. Hattersley-Smith of Starving sailors. The influence of nutrition on naval and maritime history, edited by J. Watt, E. J. Freeman and W. J. Bynum. London, National Maritime Museum, 1981,212 p. Soft cover $\{5.95$.]

Many of the early expeditions that ventured into the polar regions were naval, and their provisioning drew on naval scales with the addition of such concentrated loods as were available. Readers of Polar Record will find much of interest in this symposium volume of papers by leading specialists in the fields of nutrition, physiology, neurology, and naval and polar history. The volume is the proceedings of an international symposium held at the National Maritime Museum, Greenwich, on 16-18 April 1980.

The discovery of vitamins and the recognition of scurvy as a deficiency disease occurred only 70 years ago. The suffering of sailors from vitamin $C$ deficiency is well documented. In a paper on the nutrition of British Arctic expeditions Ann Savours and Margaret Deacon make excellent use of this material, (also of E. J. C. Kendall's research of 1955), presenting the scurvy problem with fascinating insights of life below decks in naval exploring ships of the last century. It is easy to be wise with our current

* British Antarctic Survey, Madingley Road, Cambridge CB3 OET. 
knowledge of vitamins, but scurvy prevention was an intractable problem for early medical officers; there were many complications, notably the unfortunate introduction about 1860 of West Indian lime juice, with half the vitamin C content of the Mediterranean lemon juice for which it substituted.

Scurvy was almost certainly a contributory factor to the loss of the polar party on Scott's last expedition; Dr Alan Rogers, physiologist on the Trans-Antarctic Expedition, provides a useful review of this and other factors leading to the disaster. He also restates his view (Rogers 1974) that Petty Officer Edgar Evans died of a subdural haematoma incurred in a crevasse fall. This is speculation; he may be right, but there were other reasons enough to account for Evans' breakdown and death. As the largest member of the party, existing on the same ration as the others, Evans might be expected to have been the first to fall prey to hypothermia or scurvy. Nor perhaps had he quite the phenomenal moral fibre of the other four members of the polar party.

Less well documented are other deficiency diseases that may be incurred by sailors. In a scholarly paper Surgeon Vice-Admiral Sir James Watt, principal organizer and editor for the symposium, has made a strong case for believing that Captain James Cook suffered from vitamin B deficiency on his last voyage, thus accounting for defects of judgment that may indirectly have led to his death.

Space allows comment on one further paper, by Professor W. R. Keatinge on hypothermia. He makes the point that in the past deaths at sea, through shipwreck or enemy action, were invariably ascribed to drowning rather than to hypothermia. At the start of World War II 'naval ships . . . were equipped for life-saving largely with devices which kept people afloat but left them immersed to the shoulders in water'. Thanks to the work of Professor Keatinge and others survival rafts are now available, but it may be asked how many of the ships and aircraft traversing the polar regions today carry proper provision for survival at sea.

The concise summary of discussions after the papers is a most useful feature of the volume. Sir James Watt and his collaborators deserve our warm thanks for this well edited and valuable synopsis of knowledge in an important field.

\section{References}

Kendall, E. J. C. 1955. Scurvy during some British polar expeditions. Polar Record, 7(51): 467-85.

Rogers, A. F. 1974. The death of Chief Petty Officer Evans. Practitioner (London), April: 2-12.

\section{TRISTAN DA CUNHA AND OTHER ISLANDS}

[Review by Martin Holdgate Charles Skilion, and Cape Town, David Philip, 1982, 256 p, illus. Hard cover £7.95]

Allan Crawford first visited Tristan over 45 years ago. Since the late 1930s he has been there many times, corresponded assiduously with his islander friends, and taken a deep interest in all matters Tristanian. During his years of service as Port Meteorological Officer in Cape Town he was officially concerned for the island's people, as the British Government's Honorary Welfare Officer for Tristan in that port. Probably nobody in the 'outside world' in the whole history of Tristan has been so closely in touch with the island community over so long a period.

It is right, therefore, that the people of Tristan and their history dominate this book. Sixteen out of 22 chapters are about the island, and another chapter deals with Gough Island, an outlying member of the Tristan group. But the book is also the story of its author's travelling, from his first visit to Tristan in 1937 as surveyor to the Norwegian Scientific Expedition (led by Erling Christophersen), through his wartime sojourn as meteorologist and liaison officer with the Royal Naval station, to his 18-month residence and later visits in the post-war period. His final long stay was with the Royal Society Expedition in 1961-62, when the settlement stood empty beneath the steam of the island's youngest volcanic cone. In between, Allan Crawford ranged more widely in the South Atlantic. With a group of six South Africans and six Tristan islanders of his own choosing he established the South African

- Department of the Environment and Department of Transport, 2 Marsham Street, London SWIP 3EB. 